\title{
Help - Mais além da era Bolsonaro
}

\begin{abstract}
Alexandre Sá ${ }^{1}$
Resumo: Através de uma escrita deambulatória, é proposta uma reflexão mais além de um posicionamento dicotômico para pensar as possíveis relações com a contemporaneidade, bem como os imbricados diálogos com as políticas identitárias.
\end{abstract}

Palavras-chave: arte contemporânea. política. Brasil. pandemia.

\section{Help - Beyond the Bolsonaro era}

Abstract: Through a rambling writing, a reflection beyond a dichotomous positioning is proposed to think about the possible relationships with contemporaneity, as well as the imbricated dialogues with identity politics.

Keywords: contemporary art. politics. Brazil. pandemic.

1 Alexandre Sá é artista-pesquisador, curador, crítico de arte e psicanalista. Pós-doutorando em História pelo PPGHUFF sob supervisão de Daniel Aarão Reis. Pós-doutor em Filosofia pelo PPGF-UFRJ sob supervisão de Rafael Haddock Lobo. Pós-doutor em Estudos Contemporâneos das Artes pela Universidade Federal Fluminense sob supervisão de Tania Rivera. É procientista com o projeto As revistas acadêmicas de Artes Visuais. Atual diretor do Instituto de Artes da UERJ e professor do Programa de Pós-graduação em Artes (PPGARTES). Sócio da Associação Brasileira de Críticos de Arte (ABCA). Membro da Associação Nacional de Pesquisadores em Artes Plásticas - Comitê de Poéticas Artísticas (ANPAP). Membro da Associação Nacional de História (ANPUH). Vínculo institucional: Universidade do Estado do Rio de Janeiro, São Francisco Xavier, 524 - Maracanã, Rio de Janeiro, R.J, 20943000. E-mail: alexandresabarretto@gmail.com. ORCID: https://orcid.org/0000-0002-7846-5145. Lattes iD: http:// lattes.cnpq.br/0137944963846547. Niterói, Brasil 
Comissão de frente

.... menina olha no espelho pelo ralo

e diz oi rato otário*, que que tu faz aí?

José Miguel Wisnik

O Brasil é um nome sem país

Caetano Veloso

A tradição dos oprimidos ensina-nos que o 'estado de exceção' em que vivemos é a regra. Temos de chegar a um conceito de história que corresponda a essa ideia. Só então se perfilará diante dos nossos olhos, como nossa tarefa, a necessidade de provocar o verdadeiro estado de exceção; e assim a nossa posição contra o fascismo melhorará

Walter Benjamin

Parecia impossivel que existisse realmente um mundo e um tempo, a não ser nosso mundo de lama e nosso tempo estéril e estagnado, para o qual já não conseguíamos imaginar um fim.

Primo Levi

O desaparecimento rápido de nossa memória nacional me parecer exigir um inventário dos lugares onde ela se incarnou de maneira seletiva.

Pierre Nora

Enquanto isso, os novos setores da classe média funcionavam como suporte ideológico do 'milagre'. Era a grande euforia do 'Ninguém segura esse país': eletrodomésticos, carro do ano, tevê a cores, Copa 70, Irmãos Coragem, compra de apartamento, de casa na praia, na montanha, disso, daquilo e muito mais. E a turma tava que tava, muito orgulhosa de si e de seu país. Portanto nada mais natural do que a gente ver, nos plásticos dos automóveis, expressões tais como 'Brasil, ame-o ou deixe-o'. Propaganda e publicidade firmes em cima, fazendo cabeça: muito riso, muito brilho, muita assepsia, muito perfume. Muita festa, grandes carnavais... Enquanto isso, dos subterrâneos do regime, emanavam odores pestilenciais, acompanhados de choro e ranger de dentes. Curioso que provenientes de jovens dessa mesma classe média.

Lélia Gonzalez

Vocês, tão liberais, tão humanos, que levam ao preciosismo o amor pela cultura, parecem esquecer que têm colônias e que nelas se mata em vosso nome.

Jean-Paul Sartre 
E quem ousará militar em favor de uma liberdade de deslocamento sem limite, em favor de uma liberdade sem limite? Quer dizer: sem lei? (...) O double bind diz respeito ao fato de que seria preciso desconstruir ao mesmo tempo, teórica e praticamente, certa ontoteologia política da soberania sem recolocar em causa certo pensamento da liberdade em nome do qual se põe essa obra em desconstrução. (...) O dia em que esse double bind, em que essa implacável contradição fosse suspensa, (...) seria o paraíso.

Jacques Derrida

Uma política da pós-verdade com certeza é um problema enorme, mas uma sociedade da pós-vergonha também é. Como menosprezar um líder que não sente vergonha? Ou caçoar de quem se vale do absurdo para ter sucesso?

Hal Foster

Cedo ou tarde, na vida, cada um de nós se dá conta de que a felicidade completa é irrealizável; poucos, porém, atentam para a reflexão oposta: que também é irrealizável a infelicidade completa.

Primo Levi

Narrar o trauma, portanto, tem em primeiro lugar este sentido primário de renascer.

Márcio Seligmann-Silva

II

Dispersão

Tentar escrever escapando de uma forma autorreferencial não é uma proposta possível e palatável nos dias de hoje. O ano de 2021 acaba de começar e tem-se a impressão que 2020 ainda existe de modo fantasmagórico. Uma sensação de presentidade avassaladora parece estabelecer um círculo infinito e de pouco movimento, que potencializa de uma vez por todas o paradigma contemporâneo do agora como jaula, mesmo aberta. Respirar nos últimos meses é um exercício árduo. Estamos no Brasil, em calamidade pública diante de uma crise sanitária jamais vista nas últimas décadas.

Embora saiba-se que a violência através da qual, minorias são gradativamente assassinadas e excluídas de um programa político responsável seja uma marca indelével da própria história do país, é impossível desconside- 
rar a absoluta falta de preparo e principalmente, de desejo, de salvaguardar grande parte da população periférica, bem como a perversidade que se instaura dentro de um processo de negociação neoliberal que revisita gradativamente uma história recente e jamais enfrentada, a ditadura.

Por certo, tratam-se de situações distintas e jamais caberia aqui a ingenuidade teórica de afirmar e reproduzir de maneira atabalhoada algum pensamento que aproxime tais momentos. Contudo, existem elementos coadunares que atravessam a ditadura brasileira (1964 a 1985) e o processo de retorno desse recalque (2016 até os dias de hoje) que merecem atenção. De forma inicialmente simplória é possível afirmar que trata-se de uma política perversa que a partir de uma prática assistencialista no pior termo, termina por estruturar ficções de representação e nacionalidade que implicam de forma recorrente na eliminação da alteridade e da diferença.

Somado a isto, é fundamental considerar o apoio intermitente na manutenção e potencialização de uma dicotomia, outrora creditada como direita e esquerda, além do apoio de considerável de parte da população que, dependendo do caso, da circunstância da fragilidade cultural e econômica, opta por ignorar com toda a força possível o conjunto de violências cotidianas vividas e feitas aos seus próximos e eventualmente, aos seus próprios irmãos na mesma comunidade compartilhada.

Não cabe aqui, inclusive por respeito a escrita e pesquisa científicas rememorar as afirmações recorrentes do atual presidente, bem como a abordagem irônica e extremamente irresponsável que optou por fazer ao longo desses 11 meses, justamente quando, mergulhados em uma sensação de caos absoluto, precisávamos além de algum gesto eficaz de seriedade e conforto, um tipo de gestão que fosse capaz de suspender a sensação de orfandade e de deriva. Opta-se aqui por não replicar tais afirmações, facilmente encontráveis em jornais e arquivos na internet, pois é fundamental não esquecer que tal tipo de explicitação do horror de uma prática necropolítica, na dureza de sua verdade genética, não surte mais efeito em parte da população que parece ter perdido o medo da própria morte, ao optar por exemplo, em lotar as praias no verão de 2021 ou insistir em frequentar bares promovendo a aglomeração, desconhecendo a lógica da sensação empática diante da dor dos outros e do quantitativo galopante de mortos.

Entretanto, é importante ainda considerar que apesar de outros governantes de outros países, talvez sem uma formação religiosamente colonial como a nossa, terem tido a humildade e a sensatez de reconhecer a morosidade na instauração de práticas públicas de saúde e a dificuldade de compreensão da gravidade do problema, o governo brasileiro ainda persiste e continuará 
persistindo em fomentar um política apolítica de riso falocêntrico enviesado que apenas encobre uma tática midiática bastante acertada de provocar o desterro de sua população, através da enxurrada de imagens-signos proferidas e que são, da ordem do improvável. Movimentando assim, histericamente, o universo informático, envolvendo sites de notícias, redes sociais e programas de televisão e como costuma-se dizer, produzindo conteúdo.

Tais ações e declarações recorrentes são estruturadas exatamente para que o foco da opinião pública, entendida aqui como o corpo coletivo de cidadãos capazes de emiti-la, possa ser deslocado para um ambiente anedótico que de fato, insiste a todo tempo na alegoria do desterro provocado, mas que se mantém, paradoxalmente, na superficialidade da primeira camada discursiva, sem abrir espaço para alguma profundidade contundente e de certa maneira, contestatória.

Por certo, pode-se justificar tal inércia pela pandemia e pela impossibilidade de saída às ruas por alguma manifestação coletiva. Sim. Isto é um dado. Absurdo e urgente. Por outro lado, se tivermos alguma responsabilidade e interesse históricos, é possível recordar com alguma recorrência que, em momentos tão devastadores como o que estamos vivendo, o movimento contestatório se deu, numa via de mão-dupla, através de um jogo extremamente estratégico entre forças específicas , opinião pública e imprensa, para atender demandas que serviram para a manutenção de uma estrutura coronelista de poder e de potencialização galopante das disparidades sociais e econômicas, na grande maioria dos casos, com o aceite do corpo coletivo. Lembrando ainda, que no caso brasileiro, tais movimentos de contestação estiveram sempre em uma posição deambulatória que elegeram de forma enevoada e consideravelmente ficcional seu constructo de poder a ser desafiado como grande Outro. Vide a complexidade de movimentos como a Marcha de Deus pela Família com Deus pela Liberdade (1964) e as revoltas de junho de 2013. Sendo assim, não é justo esquecer que as ditaduras são construídas, estabelecidas e suportadas também pela luta política, por mais paradoxal que isso possa parecer.

III

Alas coreografadas

Em 2020 e 2021, tais estratégias são endossadas por uma apolítica de saúde pública que em momento algum reuniu esforços suficientes para a compra de vacinas, bem como pela retroalimentação de uma cena governamental 
que insiste em ironizar a catástrofe através de uma abordagem que é inquestionavelmente genocida. Mas mais que isso, trata-se de uma tática de propulsão da clausura cotidiana, de modo a adiar eventuais descontentamentos públicos, bem como acirrar a angústia coletiva, insuflada por pronunciamentos políticos que destroem qualquer lógica de compreensão, auxiliando ainda na sensação de não acolhimento e na entropia inevitável do presente que desconhece seu amanhã. A tal avesso surrealista no pior sentido, já que nada guarda em si de inconsciente, é agregado um conjunto de protestos negacionistas que insistem em recusar a vacina e são capazes de ironizar inclusive, àqueles que seguindo uma lógica natural e lúcida, reivindicam, mesmo que apenas nas redes sociais, seu direito à saúde e à segurança, condições supostamente decorrentes do pagamento monumental de impostos.

É certo que também existem ao redor do mundo negacionistas, da mesma forma que existem nazistas e fanáticos religiosos. Não se trata especificamente de uma tragédia brasileira. Mas ao mesmo tempo seria extremamente ingênuo não considerar a quantidade e o efeito de tais posições dentro do cenário do país, que foram responsáveis por um silêncio bastante apaziguador diante de alguns golpes na história recente, que terminaram por aceitar o processo de desmantelamento de algum desejo de diminuição da desigualdade e que culminaram com a vitória, mais uma vez, de um clã político que defende seus próprios ideais e acirra, como se em eterno retorno, a discrepância estrutural entre as classes.

Obviamente, houve um legado específico para que tal cenário se descortinasse e por certo caberia uma série de outros artigos para o debate sobre tais elementos que estiveram presentes inclusive em governos anteriores que de fato, tentaram se comprometer com alguma democracia. Mas a situação particular na qual estamos mergulhados, impossível de ser compreendida pela totalidade de sua violência, pode nos conduzir a uma impressão de que vivemos apenas de mais um surto de ignorância coletiva passível de ser resolvido pelas gerações através do ensino e da formação.

No caso brasileiro, embora seja o ensino um elemento estrutural que precise de atenção, já que ainda é fragilizado em diversas regiões do país, tal proposta é insuficiente. Não se trata unicamente de ensino, mas de deformação ética, historicamente fundamentada, que retroalimenta a farsa das relações de modo a promover e provocar o proveito próprio, desconsiderando suficientemente a responsabilidade pública e a devolução salutar da confiança depositada no exercício de sua ação que, obviamente, pode ser micropolítica, individual, rotineira e mínima. Desse sintoma, escapa-se muito pouco nessas terras de aqui. Onde, dependendo do caso, a violência também transveste-se em cordialidade. 
Importante ainda destacar que estas considerações não se propõem a ser político-partidárias, embora haja uma lucidez inevitável no reconhecimento do horror possível e ainda presente de uma extrema direita brasileira que é, um arremedo de outras ao redor do mundo, em virtude de sua pouca fundamentação teórica e de sua aposta, talvez por sua incapacidade, na ignorância e na certeza do injustificável. Contudo, seria também enganado desconsiderar o rebatimento especular de alguns grupos de extrema esquerda, inclusive àqueles que insistem em uma militância pouquíssimo dialógica. Além disso, se tivermos desejo e coragem suficientes para pensarmos nossa história recente, não é possível, como feito por alguns pesquisadores capturados pelo maneirismo de seus métodos, que nos deixemos nos apaixonar cegamente por aquilo a ser investigado. E sendo assim, talvez seja urgente ultrapassarmos uma oposição meramente dicotômica para que consigamos estruturar algum pensamento que pelo menos tente escapar de seus dispositivos de poder e dominação.

Por certo, não é possível esquecer o desejo e a proposta de diminuição das disparidades sociais e econômicas dos governos do PT no Brasil. E é óbvio que, nas eleições de 2018, votei no professor Fernando Haddad. O fiz, não por ser ou acreditar em qualquer partido que seja, mas por saber, sem precisar de muita reflexão que é inaceitável, injustificável e decididamente imperdoável votar em um personagem sem efetivas ações públicas e que durante a sua campanha, feriu e ironizou as minorias: pretos, mulheres e LGBTQIA+. Surpreendentemente, a maioria dos brasileiros. Além de ser uma persona que termina aderida a uma ala militarizada retrógrada que, em momento algum, desejou alguma atualização.

Contudo, enquanto escrevo, não é possível esquecer por justiça e fé ainda em alguma democracia, de situações como Belo Monte ${ }^{2}$, que de fato, não foram discutidas suficiente como estudo de caso e que reúne, conclama e faz gozar, de forma paradoxal, eixos aparentemente dissonantes da política. Debate esse que ainda precisará ser atravessado para que não incorramos naquilo que Daniel Aarão Reis chama de memória do silêncio, ou o hábito permissivo da cultura histórica no Brasil de "olhar para frente, ignorar o espelho retrovisor" (REIS. 2019, p. 275). Além disso, é fundamental que também seja feito um esforço coletivo para reconhecermos algum maneirismo tropical da onipresença do nacional-estatismo como elemento estrutural da política e da formação social brasileira, passível de

2 Para maiores informações, seguem dois artigos de Eliane Brum, publicados no El País: https:// brasil.elpais.com/eliane_brum/2019-12-05/belo-monte-a-obra-que-une-os-polos-politicos.html https://brasil.elpais.com/brasil/2019/10/24/opinion/1571924140_406343.html 
ser identificado em alguns momentos:

a ditadura do Estado Novo (1937-1945); os anos democráticos e 'dourados' de Juscelino Kubitschek (1955-1960); os 'anos de ouro e de chumbo' do governo Médici (1969 - 1974); e finalmente, os dois governos de Luiz Inácio Lula da Silva (2003 2010)" (REIS, 2014, p. 15)

De todo modo, é importante esclarecer que aqui não há nenhuma tentativa de equiparar as relações entre direita e esquerda como se fossem vertentes aparentemente opostas com tônus próximos de dominação. Relembrar e propor a investigação da particularidade de tais governos é necessário para que se consiga, inclusive, detectar, os restos de especificidade que ainda sustentam tais proposições. Por outro lado, é impossível reiterar uma política absolutamente dicotômica e extremamente aguerrida, cegando-nos para espaços deambulatórios de desconhecimento proposital de suas ideologias originárias, passíveis de cooptação.

Chantal Mouffe defende em Sobre o político uma abordagem de tais diferenças que não esbarre na ingenuidade de uma democracia sem partido, cosmopolita ou da boa governança, já que isso viria a suprimir o caráter inerradicável do antagonismo subjetivo (MOUFFE, 2015. p. 3), indicando que não insistamos na operacionalização de uma lógica liberal que persevera em uma promoção discursiva da igualdade e da pasteurização para poder provocar, no fundo, um processo de dicotomia extremamente beligerante. Chantal Mouffe sugere que a real possibilidade de enfrentar tal debate é a partir de uma perspectiva agonística, na qual uma esfera pública vibrante propiciaria a confrontação de diversos projetos aparentemente hegemônicos. Tal proposta preconiza o investimento de forças num certo tipo de decadência que antecede o fim da própria ideologia, promovendo disputas intermitentes que conseguiriam escapar da clausura do político na esfera moral. (MOUFFE, 2015. p. 3).

O que acontece é que hoje em dia o político é jogado para a esfera moral. Em outras palavras, ele ainda consiste numa dicotomia nós/eles, porém, em vez de ser definido por meio de categorias políticas, o nós/eles agora é estabelecido em termos morais. No lugar do conflito entre 'direita e esquerda' vemo-nos diante do conflito entre 'certo e errado'. (...) Meu argumento é que, quando não existem canais disponíveis por meio dos quais os conflitos poderiam assumir uma forma 'agonística', eles tendem a surgir de maneira antagonística. Ora, quando, em vez de ser formulado como um confronto político entre 'adversários', o confronto nós/eles é visto como um confronto moral entre o bem e o mal, o oponente só pode ser percebido como um inimigo a ser destruído, e isso não favorece um tratamento agonístico. Daí a eclosão generalizada de antagonismos que questionam os próprios parâmetros da ordem existente." (MOUFFE, 2015. p. 5). 
Escolha do samba

Insistindo em não sucumbir ao esquecimento, é importante detectar alguns eixos axiais que foram determinantes para que nos encontremos na atual situação no Brasil. Um deles é a repetição de ideologias ditatoriais dissimuladas em uma prática discursiva que defende algo de democracia fantasmática. Ou de outra maneira, a conjunção discursiva e não obrigatoriamente efetiva de um exercício democrático que vela e recalca estruturas ditatoriais e oligárquicas definidoras do país. Outro eixo possível e de funcionamento paralelo, é a falta de organização de alguns partidos políticos na manutenção de seus elementos fundadores, gerando um apagamento da urgência estrutural das reformas de base. Tal descompromisso revela uma aproximação histórica daquilo que as práticas neoliberais têm de pior: o pódio do poder.

Também é impossível desconsiderar a ausência absoluta de vontade de alguns setores da sociedade em revisitar de maneira corajosa o suficiente o legado ditadorial, fato esse também justificado pela falta de empenho dos militares no esclarecimento de suas operações passadas, passível de ser percebida diante da renitente dificuldade de acesso a dados relevantes sobre o tema, aliado a um projeto extremamente questionável de anistia, que desemboca em uma Constituição "democrática" em 1988 repleta de referências e práticas econômicas e políticas do regime anterior.

\begin{abstract}
Apesar das inegáveis conquistas da nova Constituição, permaneceu inalterado nela o modelo econômico de sociedade construído - e reforçado pela ditadura: a hegemonia do capital financeiro, consolidada nos anos 1970, apoiada e incentivada pelo Estado, gestada no contexto de um processo notável de monopolização do sistema bancário e de sua articulação com os capitais comercial e industrial; a predação do meio ambiente, dada pela exploração intensiva das fronteiras agrícolas, impulsionada pelo agronegócio, concentrador de terras e de rendas, expulsando milhões de famílias camponesas para as periferias das grandes e médias cidades; e também pelas obras faraônicas de infraestrutura, quase sempre projetadas e realizadas ao arrepio de qualquer controle ou garantia de respeito ao meio ambiente, agenciadas por grandes empreiteiras, muitas delas criadas à sombra da ditadura, e que exerciam nefasta influência nos governos civis subsequentes e no próprio curso da construção democrática do país, financiando e corrompendo os partidos políticos e os processos eleitorais; as desigualdades sociais e regionais, já denunciadas ainda na primeira metade dos anos 1960, tradicionais na sociedade brasileira, mas que foram radicalizadas de forma exponencial pela ditadura; a dinamização caótica das grandes cidades e das megalópoles, hostis à vida, organizadas em torno e a serviço do carro individual." (REIS. 2019, p. $279-280$ ).
\end{abstract}

É surpreendente como este texto, produzido em 2019, explicita de forma contundente práticas que foram potencializadas pelo governo Bolsonaro ao 
longo dos anos de 2020 e 2021, estimulando midiaticamente um retorno estratégico a tais fissuras antidemocráticas para a consolidação de um sistema histórico que é fundamentado pelo aumento das disparidades sociais, pela ausência absoluta de vergonha na preconização dos interesses individuais ou de grupos específicos, e pelo estreitamento da beligerância entre setores da sociedade, não necessariamente por suas opiniões e defesas particulares.

Outro motivo para a atual situação política no país é o esvaziamento e o descrédito do exercício político, fruto de uma certa diluição de fronteiras entre os elementos determinantes de alguns partidos políticos que historicamente poderiam vir a se responsabilizar por um fortalecimento do debate público e pela organização dos interesses em torno de uma certa vocação originária reformista.

A isso, podemos somar uma ampliação considerável do acesso midiático e da utilização maciça das redes sociais como forma de comunicação não necessariamente aprofundada, baseada fortemente em sua alegoria inevitável e um certo descompromisso com a informação e suas respectivas fontes, traduzindo uma lógica de pouco cuidado na disseminação das imagens e das notícias, amparada pelo seu anedotismo e espetacularização, capazes de promover seu semblante de acolhimento e promoção das opiniões individuais, elementos esses amplamente utilizados pela militância radical.

\begin{abstract}
A paralisia e a incapacidade dos principais partidos reformistas (PT e PSDB), demasiadamente envolvidos na gestão do sistema para projetar uma reforma abrangente de suas bases, combinada com a ostensiva concentração de renda e de privilégios, exasperaram a população, que não encontrava respostas completas para suas demandas. Nessa atmosfera, a expectativa ainda depositada no PT e no PSDB se tornou mais resultado da nostalgia do que houve de melhor em seus anos de governo do que propostas transformadoras. Tucanos e petistas viraram cúmplices e reféns de um sistema que foram incapazes de mudar, perdendo uma chance histórica que é difícil estimar agora quando e se retornará. Mesmo porque os avanços obtidos em seus governos, (...) enfatizaram muito mais a multiplicação de consumidores do que a construção da cidadania. Ampliar o consumo, consumir mais e melhor, tornou-se a aspiração fundamental das pessoas, desestimuladas a participar e controlar os instrumentos de poder e os governantes. Esse aspecto, já apontado, mas ainda não avaliado em todas as suas consequências políticas, potencializou sem dúvida, a descrença no regime político." (REIS. 2019, p. 283).
\end{abstract}

O desfile

Em seu livro mais recente, Hal Foster lança uma pergunta já no título: o que vem depois da farsa? Por certo é possível considerar um primeiro movimento em aberto que é fundamental: qual farsa? A qual farsa ele se refe- 
re ou melhor, quantas farsas podemos elencar dentro de um processo histórico que norteia o país desde a sua fundação? Embora o autor esteja se referindo a um panorama americano e potencialmente característico do norte, é curioso como algumas considerações iniciais são completamente cabíveis para nós, aqui.

Inicialmente ao comentar o traço traumático para pensar uma exposição realizada de setembro de 2011 a janeiro de 2012, ou seja, dez anos depois, no MOMA-PS1 e curada por Peter Eleey, Hal Foster problematiza a obra de arte em sua relação com o evento traumático. Como o curador não necessariamente escolheu trabalhos que foram concebidos posteriormente ao 11/09, a possibilidade de expansão e diluição espaço-temporal já soam problemáticas pois todo e qualquer risco traumático guarda consigo, como imagem e experiência, elementos de familiaridade e estranheza que só se descortinariam a posteriori.

Hal Foster discute de maneira considerável, como é possível que, em algumas situações expositivas, as obras e as imagens dos trabalhos em exibição, numa imbricada relação com o conjunto e com a proposta curatorial, podem deslocar e esvaziar elementos fundadores de suas poéticas. De alguma forma, o autor nos alerta para o risco do maneirismo curatorial que termina por deslizar para o lugar, também em trânsito, de significantes em flutuação convertidos em significantes contundentes. (FOSTER. 2021, p.23)

Neste caso específico, a transmutação política proposta pela curadoria estabeleceria uma outra cadeia de significantes que uniria tais trabalhos em uma outra situação diretiva proposta a priori e não necessariamente, legítima. Por certo, se ingênuos fôssemos, poderíamos responder que talvez seja esse um devir da prática curatorial: o estabelecimento de vínculos conceituais, narrativos, históricos, formais, visuais, simbólicos entre os trabalhos. De fato, o é. Contudo, o que Hal Foster aponta é a possibilidade da exposição como uma sendo parte de uma prática curatorial-readymade que desconsidera os elementos estruturais das obras e que insiste em uma urgência também expográfica e não menos midiática que é no fundo, amparada pela segurança do seu espaço de poder e visibilidade. Se em seu célebre texto, $O$ artista como etnógrafo, o autor apontava para o risco de patronato ideológico do trabalho de arte em relação ao outro cultural, aqui, o tônus do perigo é outro: trata-se de um risco iminente de patronato ideológico curatorial que desconsidera a estranheza do trauma, ao promove-lo unicamente pelo mais-de-gozar de sua fetichização como imagem.

Por certo, é possível lembrar que esse risco de servir-se a outrem que não viveu a experiência abismal da falta, aqui no caso efetivado uma proposta 
curatorial, seria parte da responsabilidade da escolha do artista, como se fosse possível creditar alguma pureza recôndita do domínio condominial dos sentidos expressos e alocados no trabalho unicamente pelo autor. Essa hipótese seria eliminada facilmente por duas razões: a primeira e mais lógica é a resposta de que o trabalho após produzido, pertence ao mundo. $\mathrm{O}$ que, por sua vez, também poderia vir a ser questionado, já que sabemos que existem camadas diferentes de artistas com históricos distintos de diversas classes sociais e que as demandas que os erigem são múltiplas e impossíveis de serem alocadas em alguma unicidade. A segunda é a de que respeitar o trabalho de arte em suas proposições vibratórias é uma demanda urgente de novas práticas expositivas que estamos precisando lidar agora, no Brasil e obviamente, no mundo, diante de uma expansão considerável da formação, da abertura gradativa do espaço da produção e da visibilização poéticas e como avesso, de uma demanda ávida e não menos desdentada do mercado de arte diante de sua fantasmagoria que mescla exotismo e culpa histórica. Então, nesse sentido e a partir do que Hal Foster indica, não caberia nenhuma responsabilização dos artistas diante da mutabilidade política do seu trabalho, inclusive porque dependendo do caso, Ihe faltariam forças suficientes para negociar com uma estrutura que é rígida e ainda ecoa potências coloniais de nossa história mais recente. A perversidade possível de transmutação contundente de uma cadeia significante construída através de um conjunto de obras é um risco iminente das instituições, dependendo de como atravessam a realidade de seus desejos, e do curador, hoje já agregado à figura outrora carismática do crítico.

Para que tudo não fique extremamente abstrato, o ideal seria neste momento, citar alguns exemplos e discutir de forma responsável situações expositivas que esbarraram em questões como essas. Contudo, apesar da "abertura democrática nas Artes Visuais no Brasil", há um vício peculiar de considerar tudo a partir da esfera pessoal e o chamamento para o debate, também dependendo da sua urgência, pode culminar com listagens possíveis de prejuízos prováveis a quem ainda insiste em propor o diálogo.

Então, revertendo um pouco jogo, talvez seja mais útil, embora desonesto, lembrarmos aleatoriamente de algumas exposições dos últimos cinco anos no Brasil, e de qual maneira eventuais exibições também provocaram um certo silenciamento das vozes que exibiu, pressupostamente tentando visibilizá-las; visibilizar esse que já seria por si só um paradoxo e um endosso de legitimação de regimes de poder. Ou ainda, elencarmos proposições expositivas e pedagógicas, também violentas, que pela sustentação no alto de suas faixas contestatórias, reduziram um conjunto considerável de trabalhos a um local específico e não menos enclausurado, a que convencionou-se chamar de identidade. Neste caso, não necessariamente, 
dialógica, múltipla e brasileira. Por certo também caberia lembrar a retroalimentação de tal fantasma identitário promovida pelo mercado internacional de arte, mas isso, pelo menos por agora, seria outro assunto.

Mais uma vez convém endossar que não estamos desconsiderando o processo legítimo de tentativa de diminuição de uma injustiça histórica factual e narrativa nas Artes Visuais que silenciou grande parte de uma minoria que, por preconceito e hábito inconsciente, não pôde estruturar redes de conexões suficientes para que o trabalho circulasse na medida justa. Nesse sentido, seria perverso apostar na inocuidade de algumas políticas institucionais que têm investido na possibilidade de reescrita inclusive da própria história da arte brasileira, dentro de uma perspectiva mais ampla, sem promover o fetiche absoluto da diferença e de nossa própria miséria estrutural. E é lógico que se considerarmos os programas, bolsas e residências que hoje investem fortemente no fomento e na aprendizagem em mão-dupla junto aos discursos minoritários, talvez possamos respirar um pouco menos sôfregos diante da nossa paradoxal responsabilidade.

Contudo, é fundamental lembrar que além do risco readymade sistêmico, houve nos últimos anos uma prática discursiva que talvez sem considerar em profundidade seu possível legado, optou pelo esvaziamento da potência política de determinados trabalhos e artistas, como se, ao priorizar um exercício de pasteurização paradoxalmente espetacular da alteridade, cumprisse seu papel institucional. Por certo, instituição aqui merece ser compreendida de maneira ampliada e caberia inclusive considerar práticas artísticas e propostas coletivas que investiram suas forças na produção de um certo tipo de imagem ingênua que, além de atender às demandas de consumo, optaram conscientemente pela estruturação de uma experiência que se aproxima de uma lógica imagético-narrativa kitsch, fundamental para as campanhas especulares que reestruturaram o nacional-populismo nos dias atuais.

VI

Sambistas

Em Kitsch, Adorno discute as possíveis relações de pasteurização estética através de uma equiparação entre boa e má música. Embora haja no próprio discurso, um juízo e uma defesa hoje já questionável da ideia de qualidade, o que aqui interessa é o próprio esvaziamento das formas, mesmo mortas, que o Kitsch opera. 
Quanto à má boa música, é escusado mencioná-la. Também ela é kitsch: irrealizada e meramente aparente, vive de sentimentos falsos. Mas dela o poder das formas mortas esvaiu completamente. Seria desejável erradicá-la. (...) o kitsch desempenha uma função social: iludi-los a respeito de suas verdadeiras condições, romantizar suas existências, propiciar que objetivos convincentes a qualquer poder lhes apareçam com a resplandescência de contos de fada. Todo kitsch é essencialmente ideologia." (ADORNO. 2020, p. 47)

Embora ainda seja controverso, o termo kitsch surge aqui como uma possibilidade de abordagem da produção poética recente que faz uso de tais elementos para estabelecer um vínculo de identificação com seu público, mas que também, em alguns casos, pode esbarrar em tal metodologia para romantizar suas condições de vida, tornando a precariedade estrutural um produto estetizado o suficiente para que o moto-contínuo do luto seja eliminado do conjunto que o erige. Nesse sentido, alguns trabalhos em determinadas situações expositivas passariam a operar em uma lógica que promove uma anestesia fundamental também preconizada pela repetição incessantemente trágica do cotidiano pelo uso indiscriminado de slogans, esvaziados por aquilo que não são capazes de colocar em luta.

Hal Foster lembra que a definição de Milan Kundera é extremamente útil para pensarmos o panorama político-imagético atual:

Essa noção de 'sentimentos fictícios', comum a muitas pessoas, mas a ninguém em par-
ticular, levou Theodor Adorno, em Teoria estética (1970), a definir o kitsch como uma
paródia da catarse. Também permitiu que Kundera, em A insustentável leveza do ser
(1984), afirmasse que seu afeto caloroso e difuso tem valor instrumental para o nosso
'acordo categórico com o ser', isto é, para a nossa anuência com a proposição de 'que
o ser humano é bom', a despeito de tudo que nele é 'inaceitável', sobretudo a realida-
de da merda e da morte, para a qual 'a verdadeira função do kitsch é um biombo que
a dissimule. Nessa definição abrangente, o kitsch arquiteta uma 'ditadura do coração'
mediante 'imagens-chave' da 'fraternidade entre todos os homens', um sentimento de
companheirismo que, para Kundera, é uma versão ligeiramente ampliada do narcisismo: 'O kitsch faz nascer, uma após outra, duas lágrimas de emoção. A primeira lágrima diz: como é bonito crianças correndo num gramado.

A segunda lágrima diz: como é bonito se emocionar com toda humanidade ao ver crianças correndo num gramado.

Somente essa segunda lágrima faz o kitsch ser kitsch.'

É também o que, em sociedades governadas por um único partido, torna o kitsch 'totalitário', e, 'no reino do kitsch totalitário, todas as respostas são dadas de antemão e excluem qualquer pergunta nova."' (FOSTER. 2021, p.26)

É interessante como Hal Foster ao citar Milan Kundera indica que o kitsch como experiência e aqui, como operação metodológica que se situa no entrecruzamento em palavra e imagem, não funciona de maneira autônoma. Além de ser estruturado como ideologia, o kitsch precisa da experiência da comoção do outro para que a fantasia da comoção de si se esta- 
beleça. Não se trata inteiramente de uma experiência individual e talvez nem mesmo inteiramente coletiva, porque se produz na prova enviesada e decalcada do sofrimento do outro, gerando por consequência o esvaziamento da potência abismal e promovendo o conforto inconsciente da experiência narcísica.

Em crítica da razão cínica, Peter Sloterdijk, filósofo alemão, opta por uma proposta consideravelmente audaciosa ao tentar elencar oito desmascaramentos necessários a uma revisão crítica do próprio cinismo, compreendido aqui, inclusive, a partir de sua perspectiva de repúdio à verdade e aderência à fidedignidade do dizer verdadeiro sem se importar fortemente com àquele ao qual a mensagem é dirigida. Na parte VIII deste desmascaramento, chamada, Crítica da razão privada, Sloterdijk indica como a mitologia do fascismo se revela, obviamente diferente da grega, distanciada e sem vergonha (SLOTERDIJK, 2012. p. 101).

Nessa mitologia, consideravelmente construída como estratégia, há uma certa tendência a um jogo especular bastante curioso entre público e privado que, segundo o autor, sofreu variações de acordo com a fundamentação narcísica da aristocracia, da burguesia, da neoburguesia e do proletariado. Segundo Sloterdijk, é na pressuposta intimidade, onde seria produzido o encontro com aquilo de mais íntimo, que terminaríamos por nos aproximar do que é mais universal. E as variações de classe, para além de uma estruturação econômica, se daria também pela forma através da qual tais eixos estruturaram as relações com seus narcisismos. Para a burguesia, a relação narcísica com a identidade e com o eu se daria, diferentemente da aristocracia, por uma afirmação do trabalho e de sua estruturação social a partir da recorrência ao esquecimento do questionamento da perversidade de tais métodos de trabalho, numa relação estreita entre capitalistas, empreendedores e agentes financeiros que terminaram por torcer princípios como sucesso, desempenho e privilégio, desembocando em uma confusão proposital entre espontaneidade patriótica e ideologia política, no século XIX, para frutificar em um sistema de desvario no século XX. (SLOTERDIJK, 2012. p. 107). O que parece relevante é como tais narcisismos, passíveis de programação e remodelamento, historicamente também foram estruturados, por um conceito consideravelmente problemático: a identidade.

\footnotetext{
A dança em torno do bezerro de ouro da identidade é a última e a maior vertigem do Contra-Esclarecimento. Identidade: é essa palavra mágica de um conservadorismo em parte secreto, em parte aberto, que escreveu em suas bandeiras: identidade pessoal, identidade profissional, identidade nacional, identidade política, identidade política, identidade feminina, identidade masculina, identidade de classe, identidade partidária, etc. A enumeração dessas exigências essenciais de identidade seria no fundo suficiente para ilustrar o caráter móvel e plural daquilo que se denomina identidade. Mas não se falaria de identidade, se o que estivesse em questão não fosse no
} 
fundo, a forma fixa do eu." (SLOTERDIJK, 2012. p. 103).

É então nessa confusão sensível e epistemológica entre identidade e narcisismo que ressurge uma outra farsa possível, amparada pela lógica da celebridade e potencializada pela paixão fictícia da comunidade, a dos irmãos que terminarão sempre assassinando seu líder, ou o pai da horda de Freud. Trata-se de um ritual mitológico inevitável e inerente que jamais teve coragem e silêncio suficientes para deixar esse espaço de mando e subjugo, desocupado. O líder é morto e na sequência, substituído. Exatamente por isso, pela insistência em realocação recorrente do poder no lugar da falta, é que a transgressão pode vir a ser cooptada por todo e qualquer regime, inclusive os mais reacionários.

Contudo talvez resida aí, nessa outra transgressão, que defende o esvaziamento contínuo de seus lugares de controle, a elaboração de um espaço ínfimo e infinito, jamais a ser completado pelo desejo de poder, uma aposta possível em um novo regime discursivo incapaz de ser apropriado e tokenizado, numa continuidade subversiva que sempre negará a fixidez, mas que concordará com uma aderência temporária às suas identificações em trânsito. Não de maneira ingênua, mas sabendo que se trata inevitavelmente de uma mera estratégia de sobrevivência. E de luta.

\begin{abstract}
A "identidade" de um tal assunto múltiplo e contraditório é sempre contingente e precária, temporariamente fixada na intersecção de tais posições de assuntos e depende de formas específicas de identificação. Esta pluralidade não envolve, entretanto, a coexistência, uma a uma, de uma pluralidade de posições de sujeitos, mas a constante subversão e sobredeterminação de uma por outras, tornando possível a geração de efeitos totalizadores dentro de um campo caracterizado por fronteiras abertas e dissuasivas. Há, portanto, um duplo movimento. Por um lado, há um movimento de descentramento que impede a fixação de um conjunto de posições em torno de um ponto pré-constituído; por outro lado, e como resultado desta não fixidez essencial, existe um movimento contrário: a instituição de pontos nodais, fixações parciais que limitam o fluxo do significado sob o significante. Mas este movimento dialético só é possível porque a fixidez não é dada de antemão, pois nenhum centro de subjetividade precede as identificações do sujeito. Por esta razão, temos que conceber a história do sujeito como a história de seus ou suas identificações, e não há identidade oculta a ser resgatada além desta última. (MOUFFE, 1992. p. 28)
\end{abstract}

Resta ainda uma provocação: como promover o lugar vazio de tal fixidez de poder de identidade como sendo uma tática de refluxo, negociação e luta frente a pasteurização inerente advinda da globalização? Será possível propor uma outra transgressão de si que, sem jamais desconsiderar o horror e a injustiça históricas, joga de maneira intermitente com um processo de aparecimento e desaparecimento de tais pontos nodais como parte de uma lógica imagética extremamente astuta, que jamais se estabelece e nem mesmo quer vir a se estabelecer em sua completude? 
Elisabeth Roudinesco em seu mais recente livro, ao citar Sélim Abou, evidencia um risco iminente que precisamos cada vez mais, considerar:

\begin{abstract}
Ele salientava ainda que quanto mais se afirma a globalização econômica, mais se intensifica, em contraponto, a igualmente bárbara reação identitária, como se a homogeneização dos modos de vida, sob o efeito do mercado, fosse aumentar, aliada à procura das chamadas 'raízes'. Nesta perspectiva, a mundialização das trocas econômicas foi, portanto, acompanhada por um recrudescência das angústias de identidade mais reacionárias: terror da abolição das diferenças sexuais, do apagamento das soberanias e das fronteiras, medo do desaparecimento da família, do pai, da mãe, o ódio aos homossexuais, árabes, estrangeiros, etc. (ROUDINESCO, 2021.n.p)
\end{abstract}

VII

\title{
Arquibancada 1
}

Claudia Tavares, artista carioca, desenvolveu um trabalho durante a pandemia que explicita e sintetiza tais questões de forma contundente. O título do trabalho é Fale comigo. Repleto de ironias, já nos pergunta sobre o próprio exercício de fala//escuta nos tempos atuais e as variações inevitáveis da comunicabilidade. Partindo de uma série de encontros e não tentando escapar da natureza deambulatória da atenção, a artista começa a perceber no outro, o ambiente e a intimidade inevitável que a câmera indica sem apontar. Dessa forma, os elementos do entorno, capazes de construir o ecossistema de referências pessoais, tornam-se protagonistas do quadro, ou talvez, do jogo de enquadramento que a imagem é capaz de proporcionar ao espectador.

E aleatoriamente, pelo processo inevitável da captura do objeto projetado que é capaz de fisgar aquele que olha, uma cor é eleita. É essa cor que de fato, após o enlace da própria artista, "antropofagiza" o sujeito outro que estabelecia algo de diálogo, apagando-o ou de outra forma, esfacelando qualquer ingenuidade possível de inteireza. A cor de fundo abre o fundo inerente do próprio sujeito assujeitado, ressaltando sua presença apaixonada pela ausência (e vice-versa), nutrida por sua incontestável e genética fantasmagoria.

Além da relação deambulatória da relação fala e escuta, aqui também surge como questão um certo esvaziamento do sujeito, já espraiado no entorno, como se a artista pressentisse a inevitável diluição inevitável das certezas estruturais de uma pressuposta identidade rígida e fixa. Resta uma memória de forma preenchida pela escolha aleatória de uma cor, como um vestígio em trânsito que pode vir a ser colorido em outras circunstâncias e a partir de outros olhares. Resta o fora. Não se trata mais de um regime discursivo fixo, mas de processos de apagamento e reaparecimento, próprios da imagem. 
Figura 1

Claudia Tavares

Fale comigo, 2020

Acervo da artista

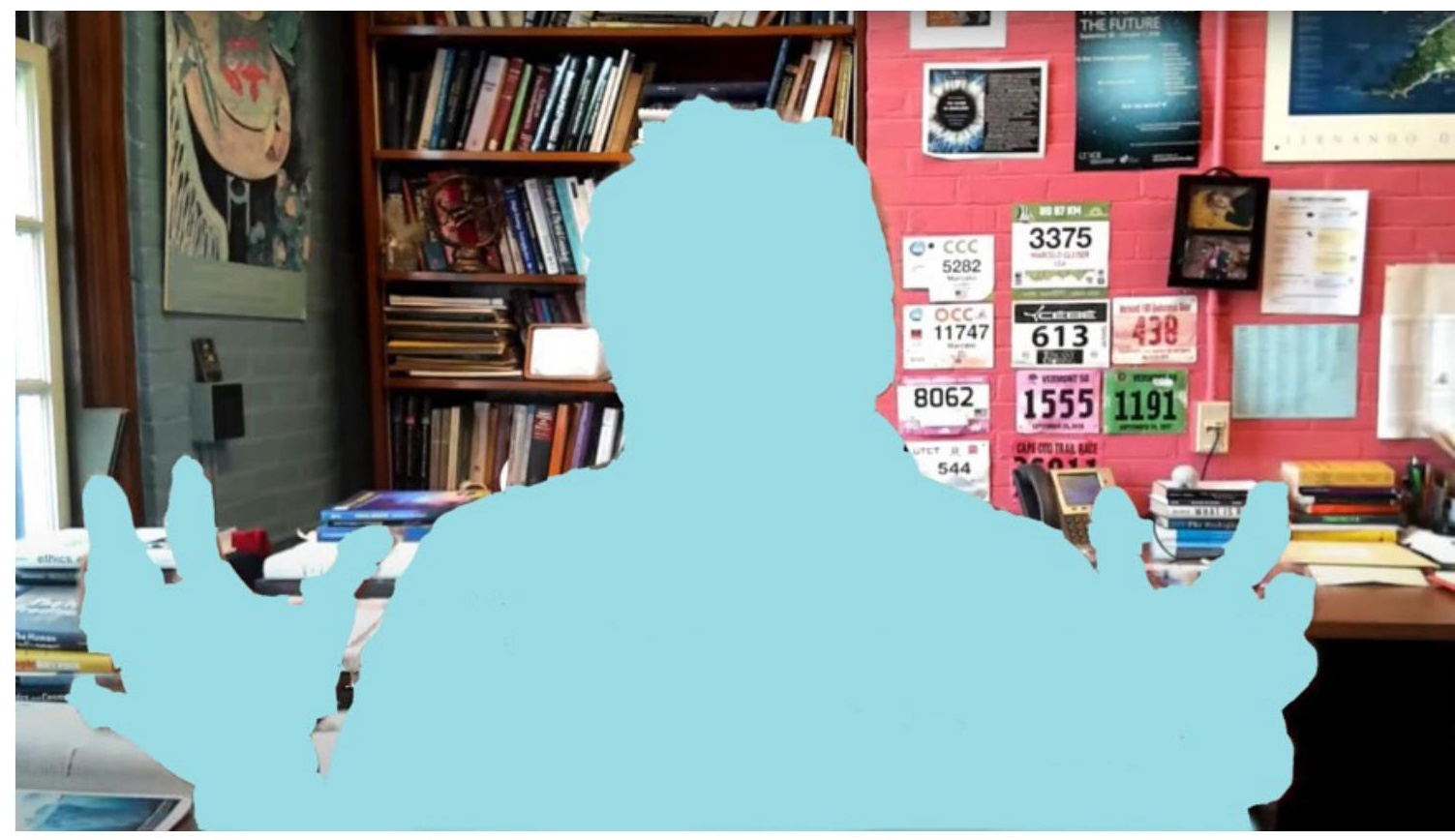

Quem vê o quê, numa tal experiência? Quem olha? Quem é olhado? Quem <<expecta >>? Quem é aguardado? Estamos, sem dúvida, diante da imagem - por mais soberana que seja - como a falena diante de sua chama. Quando partimos alegremente para uma caça às borboletas, sabemos verdadeiramente quem será a verdadeira presa e quem será o verdadeiro caçador? (DIDI-HUBERMAN, 2015. p. 36)

Didi-Huberman em Falenas, discorre sobre a estética e a lógica da aparição que viria inevitavelmente (e obviamente) aderida à desaparição, através de uma linda metáfora poética: a falena. Tal espécie como algumas borboletas, sempre são atraídas pela luz que paradoxalmente as desorientam e as seduzem; fazendo com que a ruína lhes chegue em virtude da desatenção diante do seu desejo junto ao fogo da pulsão entre a vida e a morte. Em outras palavras, as falenas deixam-se morrer pelo desejo de iluminação e surgem como um epíteto da metamorfose de toda e qualquer imagem que aparece e desaparece em sua vontade de encontrar algo que pressupostamente a fulgure; ou seja, algo que a revele, que a traduza e que lhe dê algum conforto.

compulsivamente, o seu corpo vai e vem sobre si mesmo, como numa dança erótica ou num transe. Depois, o ser que borboleteia, erra e agita-se à toda, arrastando seu corpo daqui para ali como que numa exploração inquieta, numa busca que decididamente ignora o objeto último. Há nesta dança algo de instabilidade fundamental do ser, uma fuga das ideias, um poder absoluto da livre associação, uma primazia do salto, uma ruptura constante das soluções de continuidade. (DIDI-HUBERMAN, 2015. p. 27)

\section{E continua:}

E isto é válido para os humanos como para as borboletas: o desejo move cada gesto, mas cada gesto do desejo comporta uma certa relação com a morte. A imago revela-se na sua 
função psíquica, tão dúplice e pulsativa quanto as asas da borboleta: ela forma o meio privilegiado para uma constituição simbólica do sujeito, mas advém facilmente <<factor morte >> e meio primeiro da destruição do outro pela agressividade que é, como entre os insetos, afrontamento mimético e espetacular.(DIDI-HUBERMAN, 2015. p. 27)

A metáfora da falena parece trazer uma associação possível para a questão do laço que aqui, também interessa abordar como uma variação da experiência estética da identidade. Didi-Huberman faz uso da lógica de funcionamento da imagem como sendo uma outra possibilidade de aproximar-se das diversas esferas da relação visual (em uma primeira instância), da mesma forma que as infindáveis (i)lógicas de confrontamento da realidade subjetiva. Haverá então, sempre, uma relação espelhada entre o ver e o ser visto, entre o ser e o ser isto; que além de ser fundamental para a constituição simbólica do sujeito, será atravessada pelo desejo, pela cobiça do desejo do encontro que, por sua vez, estará envolto por uma presença absoluta da morte, numa relação de intermitência infinita.

É curioso pensar que a palavra falena vem do grego phalaina que, segundo o Dicionário etimológico da língua portuguesa de 1955, é o mesmo radical da palavra baleia. Em certo sentido, os dois animais têm uma conexão análoga de existência, considerando suas deambulações entre o aparecimento e o desaparecimento. Se a falena, no meio da noite, abre e fecha suas asas para que se movimente, da mesma forma que já havia em seu passado um abrir-se para a vida fora do casulo; a baleia, envolta em seu ambiente natural, também absolutamente particular, vive numa pulsão dialógica brincante entre o aparecer e o desaparecer. Sua presença diante de nossos olhos é apenas um lampejo de visão, um instante, uma pequena iluminação, um salto para que na concretude de um mundo que não inteiramente seu, ou seja, para que na atmosfera desconfortável das coisas necessárias, esvazie os seus pulmões para posteriormente mergulhar e sumir mais um pouco na infinitude marítima.

Agoniza mas não morre é o primeiro movimento de uma série de trabaIhos em que Felippe Moraes destaca trechos afetivos de músicas e os coloca em suspensão na janela de seu apartamento próximo ao viaduto Santa Efigênia, no centro de São Paulo. Aqui, neste caso, o verso de Nelson Sargento ganha novos timbres, talvez fantasmáticos, na pausa opressiva inevitável de um problema de saúde pública, aliado a falta de responsabilidade com o coletivo, permeado por uma abordagem necrófila. Se originalmente, a música narra as transições estruturais do samba, sua cooptação, pasteurização e sua imposição na cultura, aqui a imagem do néon surge como um exercício de resistência, na fé imbricada do possível, guardando de maneira delicada, o silêncio respeitoso de um lamen- 
to que nos acomete nos dias atuais.

O trabalho foi viabilizado pela Lei Aldir Blanc do Estado de São Paulo. O que também parece contundente neste caso, é a escolha do artista em utilizar seu próprio o apartamento, como área em trânsito, de negociação e pela possibilidade de apreensão do trabalho como um movimento entre o espaço íntimo e o espaço público, como se possível uma situação ideal entre o gás neón e o infrafino político que estrutura a fita de moebius entre eu e tu. A frase, agoniza mas não morre, além de indicar um desejo e uma urgência individual, termina por espraiar-se na multidão arquitetônica e entrópica da cidade, sem acreditar jamais em generalizações e investindo suas forças na potência mínima de alguma revolução que resiste ao apagamento.

Felippe Moraes Agoniza mas não morre, 2021

Da série

Samba exaltação Foto: Gabriel Cabral

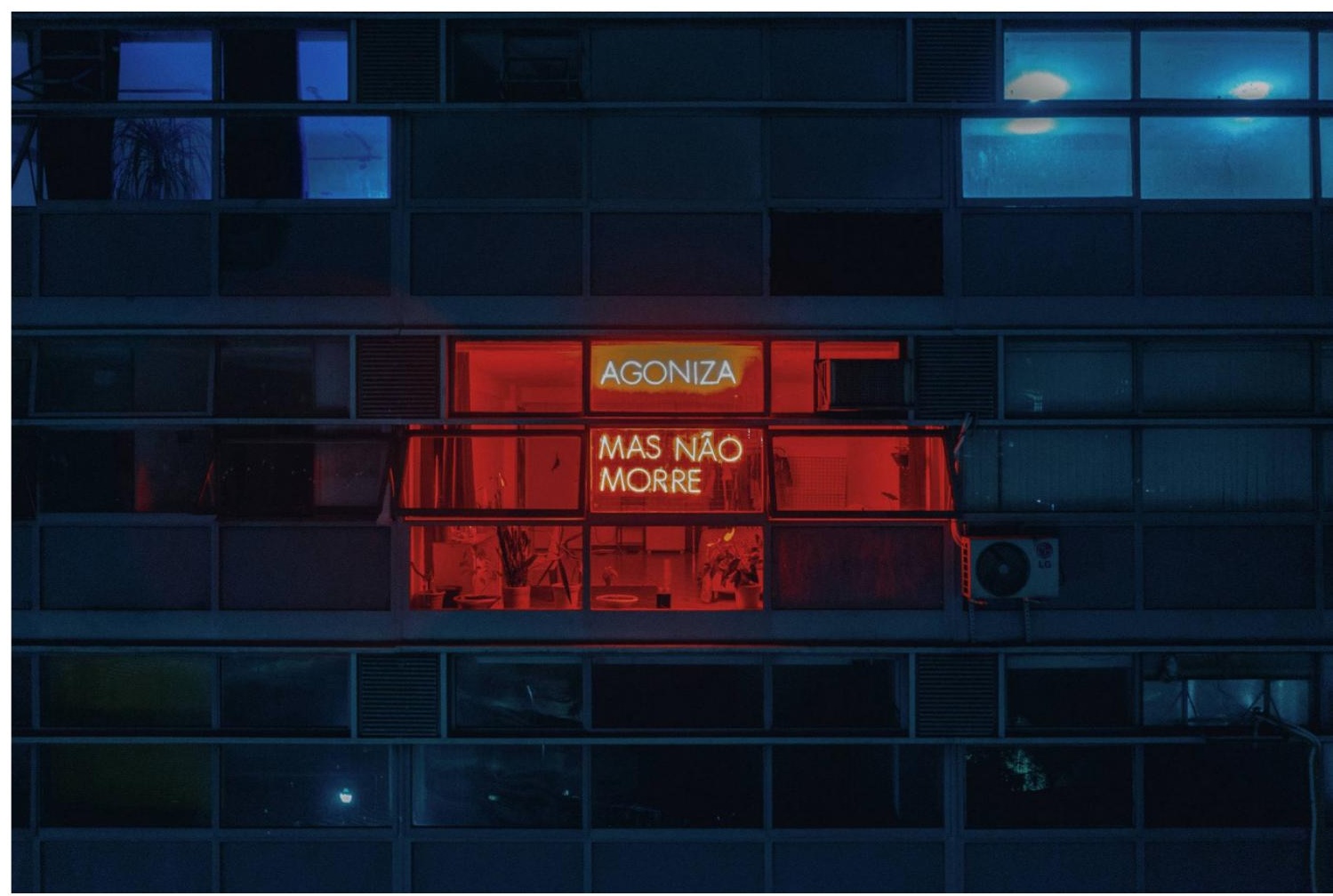

A solidão também ressurge potencializada em outra imbricada camada entre público e privado. Se por um lado, sair e existir o espaço do mundo é risco de morte, por outro, manter-se no mundo é sustentar o estar em si dialogando com o risco intransponível da intimidade devassada das telas, aplicativos e conexões. O liame entre eu e outrem, talvez como resultado de um atabalhoado processo de construção que insiste em desconsiderar seu passado, é esfacelado. O que resta é a saudade nostálgica de um tempo futuro. Em eterno porvir. A ser acendido e apagado. Como se numa parede invisível de uma caverna íntima em que a expressão pura do viver ainda urge. 
Chico Fernandes propôs uma ação recente que potencializa suas últimas pesquisas corporais diante do risco do existir em uma atualidade devassadora. Trata-se de um jogo perverso de exposição visual aos perigos cotidianos enfrentados por grande parcela da população, discutindo a presença do corpo como imagem, resto e também, algo de memória. A pluralidade das propostas anteriores também se vincula semanticamente à incompreensão nodal do trabalho por um público mais amplo, num diálogo afiado e tenso com dispositivos de controle, forças policiais e outros regimes disciplinares, revisitando inclusive uma herança inevitável dos anos 1960, sem melancolia alguma, mas atravessado por um desejo de atualização e enfrentamento de questões poucos debatidas ao longo da história no Brasil.

Em Eu sou eu e o cavalo não é meu, de 2021, o artista realiza uma ação no Monumento à Guerra do Paraguai, localizado na Praça XV, no Rio de Janeiro, que consiste em colocar uma escada, escalar o conjunto escultórico e do alto, tirar sua sunga e completamente nu, fazer um discurso com um megafone (que pertenceu a outro artista, Aimberê César) sobre as condições atuais de horror, desamparo e esvaziamento político. Neste caso, o trabalho foi finalizado com a já prevista postura truculenta da vigilância e o encaminhamento do artista e dos amigos que acompanharam o processo, à uma delegacia para que os trâmites burocráticos fossem estabelecidos.

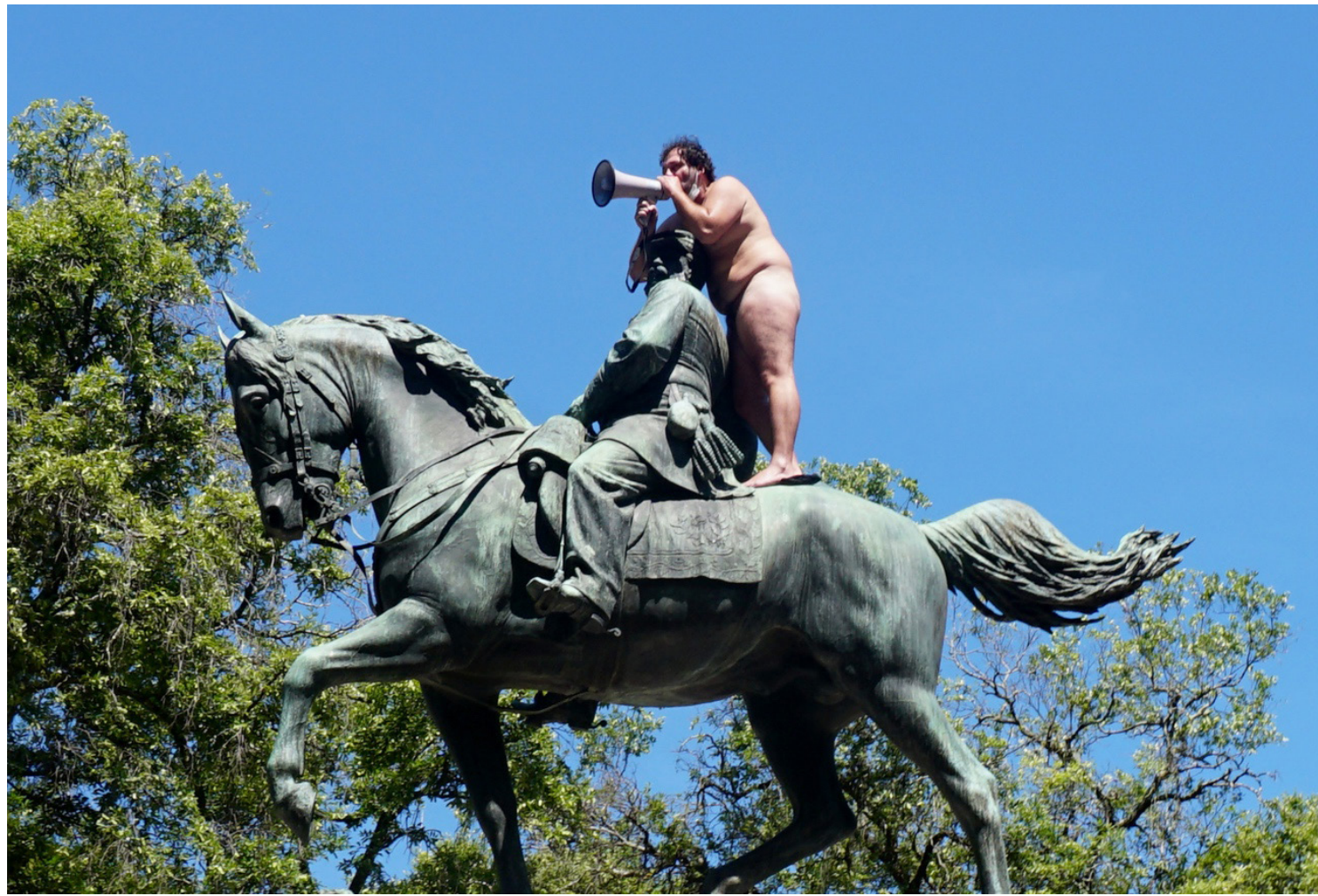


Mais além da imagem, há uma parcela considerável da proposta que escapa da ação veiculada, já que o que viralizou nos grupos de Whatsapp de todos os tipos, bem como das famílias ainda capazes de marchar com Deus pela ética e pela moral, foi a ação inusitada, a imagem torpe e o descalabro do sujeito fraturado por sua própria crise que talvez, num movimento fidedigno ao seu desejo histérico, opta por não fazer calar aquilo que se deseja calar: que estamos mais do que nunca, à deriva. Se é isso que circula como questão e anedota junto a um público ampliado, e se muitas outras camadas simbólicas e mesmo imaginárias são desconsideradas, talvez reste-nos agradecer a coragem outra de nos jogar em uma área difusa e extremamente nebulosa, onde a arte, enquanto identidade necrosada, decididamente, não cabe mais.

\section{Referências}

ADORNO, Theodor W. Indústria cultural. São Paulo: Editora UNESP, 2020.

FOSTER, Hal. O que vem depois da farsa? Arte e crítica em tempos de debacle. São Paulo: Ubu Editora, 2021.

DIDI-HUBERMAN, Georges. Falenas. Ensaios sobre a aparição, 2. KKYM. Lisboa; 2015.

MOUFFE, Chatal. Citizen and political identity. In: OCTOBER (MIT Press), Cambridge, vol. 61, Summer 1992, p. 28 - 32.

Sobre o político. São Paulo: Editora Martins Fontes, 2015.

REIS, Daniel Aarão, RIDENTI, Marcelo \& MOTTA, Rodrigo Patto Sá. A ditadura que mudou o Brasil. Rio de Janeiro: Jorge Zahar Editora, 2014.

REIS, Daniel Aarão. As armadilhas da memória e a reconstrução democrática. In: Democracia em risco? 22 ensaios sobre o Brasil hoje. São Paulo: Companhia das Letras, 2019.

ROUDINESCO, Élisabeth. Soi-même comme um roi. Paris: Seuil, 2021.

SLOTERDIJK, Peter. Crítica da razão cínica. São Paulo: Estação Liberdade, 2012.

Recebido e aceito em 28 de Março de 2021.

Este é um artigo publicado em acesso aberto sob uma licença Creative Commons (cc)) BY 